TERESA RZEPA ${ }^{1}$

Studia Psychologica

UKSW

Uniwersytet SWPS

Wydział Zamiejscowy w Poznaniu

16(1) 2016 s. 47-69

\title{
O PSYCHOLOGICZNEJ I WOJENNEJ MISJI TWÓRCY SZKOŁY LWOWSKO-WARSZAWSKIEJ
}

STRESZCZENIE

W artykule omówiono podwójną misję, która została idealnie spełniona przez Kazimierza Twardowskiego, założyciela Szkoły Lwowsko-Warszawskiej. Swoją misję psychologiczną Twardowski realizował przez całe życie, podczas gdy misja wojenna trwała trzy lata (1914-1917), kiedy to pełnił on funkcję rektora Uniwersytetu Lwowskiego. Opisy obu misji poprzedza krótki rys biograficzny Kazimierza Twardowskiego.

Słowa kluczowe: założyciel Szkoły Lwowsko-Warszawskiej, misja psychologiczna, misja wojenna

\section{ON PSYCHOLOGICAL AND WAR MISSION OF THE FOUNDER OF THE LVOV-WARSAW SCHOOL}

\begin{abstract}
The double mission, ideally fulfilled by Kazimierz Twardowski, the founder of the Lvov-Warsaw School, is discussed in the article. Twardowski fulfilling his psychological mission all his life while the war mission lasted three years (1914-1917), when he was carrying out the role of the president (rector) of the Lvov University. A short biography of Kazimierz Twardowski precedes the descriptions of those missions.
\end{abstract}

Keywords: the founder of the Lvov-Warsaw School, psychological mission, war mission

\section{WPROWADZENIE}

Kiedy 15 listopada 1895 roku 29-letni Kazimierz Twardowski (1866-1938) objął Katedrę Filozofii w Uniwersytecie Lwowskim, można było oczekiwać, że naukowa aktywność profesora skoncentruje się na filozofii. Jednak każdy, kto w tamtych czasach tak jak Twardowski uważał siebie za filozofa nowoczesnego, zajmował się również psychologią - dyscypliną modną i szybko zdobywającą rzesze zwolenników. Na psychologicznych zainteresowaniach Twardowskiego oraz na podjęciu misji szerzenia psychologicznej wiedzy w znacznym stopniu

1 Adres do korespondencji: trzepa@swps.edu.pl. 
zaważył przebieg jego drogi edukacyjnej i socjalizacyjnej oraz spotkane na tej drodze osoby.

Kiedy w czerwcu 1914 roku 48-letni Kazimierz Twardowski został wybrany na rektora, można się było spodziewać, że jego organizacyjna działalność skoncentruje się na sprawach uczelnianych, a aktywność naukowa i dydaktyczna będzie przebiegała zgodnie z rygorystycznie przezeń przestrzeganymi planami. Jednak nie było mu to dane. Na trzech latach jego życia naznaczonych pełnieniem funkcji rektora Uniwersytetu Lwowskiego i na wyjątkowej misji, jaką wówczas pełnił, zaciążyła I wojna światowa.

Niniejszy tekst traktuje o tych dwóch rodzajach misji, które Twardowski z perspektywy oceny dokonanej współcześnie - wypełnił wzorowo, i to przed rokiem 1918, czyli przed odzyskaniem przez Polskę niepodległości po latach austriacko-prusko-rosyjskich zaborów. Zanim przejdę do omówienia istoty i przebiegu owych misji, kilka zdań na temat historii życia Kazimierza Twardowskiego.

\section{Droga ŻYCIOWA}

Twardowski wychował się $\mathrm{w}$ wiedeńskim katolickim domu, przepełnionym atmosferą urzędniczej powagi. Był najstarszym synem Malwiny Kuhn (1844-1932), córki aptekarza z Przeworska, oraz Piusa Twardowskiego (1828-1906), prawnika, który pochodził z Kamieńca Podolskiego i który przez całe swoje życie piastował coraz wyższe stanowiska urzędnicze. Nic więc dziwnego, że podobnie postrzegał karierę swojego syna i w tym celu podjął starania o pozyskanie dlań stypendium z funduszy Galicyjskiego Wydziału Krajowego. W rezultacie ojcowskich zabiegów jedenastoletni Kazimierz został uczniem Theresianum, znanego z dyscypliny i rygoru szlacheckiego gimnazjum męskiego (z pensjonatem), gdzie przygotowywano chłopców do kariery urzędniczej, dyplomatycznej lub wojskowej. Młody Twardowski od pierwszej klasy był prymusem, a pod koniec nauki, w 1884 roku, otrzymał złoty medal szkoły. Z pobytu w Theresianum Kazimierz wyniósł nawyk dyscypliny i harmonii wewnętrznej, stoicką postawę, kult dla odpowiedzialnej, rzetelnej i systematycznej pracy, niezłomne zasady etyczne, zamiłowanie do logicznego myślenia i bezwzględnego ujawniania błędów w rozumowaniu (Twardowski, 1992).

Po maturze, zdanej 13 lipca 1885 roku z wynikiem bardzo dobrym, z początkiem grudnia tego samego roku Twardowski przyjął posadę nauczyciela domowego w naddniestrzańskim majątku polityka i filozofa hrabiego Wojciecha Dzieduszyckiego (1848-1909). Właśnie tam, w Jezupolu, poznał swoją przyszłą żonę, Kazimierę Kołodziejską (1862-1945). Ich ślub odbył się 9 stycznia 1892 roku (Jadczak, 1992).

Rok po maturze (1886) Twardowski podjął studia filozoficzne w Uniwersytecie Wiedeńskim, dzieląc odtąd swój czas na obowiązki studenta i jednocześnie nauczyciela u Dzieduszyckich. Oprócz przedmiotów filozoficznych studiował 
historię, matematykę i biologię. W latach 1889-1890 odbył służbę wojskową. Od pierwszego roku studiów jego nauczycielem był Franz Brentano (1838-1917), którego osobowość wywarła na Twardowskim „największe wrażenie”. Wkrótce został jego „bliższym” uczniem, a relacja z mistrzem przybrała „nieoceniony charakter osobisty", dający mu prawo do niezapowiedzianych odwiedzin w domu Brentana (Twardowski, 1992). W rezultacie wielogodzinnych dyskusji, możliwych dzięki wyjątkowości tej relacji, Twardowski przejął większość naukowych poglądów swojego mistrza (Brentano, 1874/1999) i ukierunkowanie „osobowości uczonego" na rolę raczej nauczyciela niż oderwanego od dydaktyki „poszukiwacza prawdy". Relacja z Brentanem wzmocniła również postawę życiową i nawyki wyniesione z Theresianum: zdyscyplinowanie, surowość obyczajów, moralną odpowiedzialność, uczuciowy stoicyzm oraz trwałe zasady postępowania. Podbudowała także wiarę w moc samodzielnego myślenia i w przedkładanie logicznych rozumowań, starannych opisów i analiz nad pochopność sądów czy wyjaśnianie niepoprzedzone deskrypcją problemu. Takie podejście stało się podwaliną dla stosowanej przez Twardowskiego tzw. metody semiotycznej, polegającej na precyzyjnej analizie znaczeń i dokładnym definiowaniu pojęć. Bezkompromisowo i otwarcie wykazywał, że zagmatwanie terminologii, nadużywanie symboli i niejasność języka świadczą nie tyle o „mądrości” wykładu czy publikacji, ile o zaplątaniu i zmąceniu myśli ich autora, które w takim razie nie zasługują ani na uwagę, ani na ich odczytywanie ${ }^{2}$ (Twardowski, 1919-1920/1965).

W czasie studiów Twardowski współdziałał przy organizowaniu Towarzystwa Filozoficznego w Uniwersytecie Wiedeńskim. W latach 1887-1889 jako wiceprezes Towarzystwa nabył administracyjnych i organizacyjnych doświadczeń, które z pożytkiem wykorzystał później we Lwowie, zwłaszcza w trakcie piastowania stanowiska rektora Uniwersytetu Lwowskiego. Obrona jego pracy doktorskiej odbyła się w 1891 roku, a rozprawa (pt. Idee und Perzeption. Eine erkenntnistheoretische Untersuchung aus Descartes) została opublikowana w 1892. Formalnym promotorem dysertacji był Robert Zimmermann (1824-1898), rzeczywistym zaś - Brentano, który pracował w Uniwersytecie Wiedeńskim na stanowisku docenta prywatnego, nie miał więc odpowiednich uprawnień akademickich

2 Rygorystycznie stosowana metoda semiotyczna, znana jako zasada „ABC porządnego myślenia" (Ajdukiewicz, 1959), miała swoich krytyków, którzy - jak np. Roman Ingarden (1893-1970) czy Tadeusz Tomaszewski (1910-2000) - uważali, że Twardowski przykładał zbyt dużą wagę do metodologii (kontekstu uzasadniania), zaniedbując przy tym aktywność twórczą (kontekst odkrycia; Ingarden, 1973; Tomaszewski, 1996). Podczas uroczystości z okazji 85. urodzin „Tomaszewski opowiadał o swych studiach w rodzinnym Lwowie. [...] Dostało się szkole Twardowskiego. Szkoła ta uczyła ciagle ostrzyć nóż, ale nie dochodziło do krajania nim chleba. Usłyszeliśmy - nie my pierwsi - że to, co tam robiono, zabijało twórczość" (Pietrasiński, 2015, s. 82). 
(Woleński, 1985; Jadczak, 1991, 1995, 1997; Twardowski, 1992; Rzepa, 1997, 1998; Rzepa, Dobroczyński, 2009).

W styczniu 1892 roku Twardowski uzyskał rządowe stypendium naukowe i wyjechał na studia do Lipska, gdzie przez trzy miesiące słuchał wykładów Wilhelma Wundta (1832-1920) z historii filozofii nowożytnej i brał udział w pracach laboratorium psychologicznego, do którego już wtedy przylgnęło miano centrum światowej psychologii. W późniejszych publikacjach Twardowski nie nawiązywał jednakże do doświadczeń związanych z tym epizodem, a w autobiografii jedynie wzmiankował o lipskim laboratorium. Dowodzi to, że nie zafascynował się uprawianą tam psychologią eksperymentalną. Ważniejsze dlań było, że w Lipsku nawiązał bliższą i trwającą przez długie lata znajomość z Oswaldem Külpem (1848-1936), twórcą szkoły würzburskiej (Zusne, 1975; Schultz, Schultz, 2008). W semestrze letnim 1892 roku Twardowski przebywał w Monachium, gdzie uczestniczył w wykładach i ćwiczeniach z filozofii prowadzonych przez Carla Stumpfa (1848-1936), psychologa muzyki i akustyki, słynnego eksperymentatora i autora pierwszej pracy psychologicznej poświęconej percepcji przestrzeni (Zusne, 1975). Ze Stumpfem (podobnie jak z Külpem) Twardowski nawiązał trwałą znajomość. Wielokrotnie był zapraszany do jego domu, gdzie wspólnie muzykowali (Twardowski, 1992).

Od jesieni 1892 do jesieni 1895 roku Twardowski pracował jako urzędnik w biurze matematycznym zakładu ubezpieczeń na życie Powszechnego Stowarzyszenia Urzędników, a ponieważ pensja, którą otrzymywał, była skromna, więc dorabiał korepetycjami i pisaniem esejów filozoficznych do miesięcznika „Przełom”. W tym czasie przygotował bardzo dobrze przyjętą i szeroko dyskutowaną w środowisku naukowym ${ }^{3}$ rozprawę habilitacyjną (Zur Lehre vom Inhalt und Gegenstand der Vorstellungen), uzyskując venia legendi w lipcu 1894 roku. W roku akademickim 1894/1895, jako docent prywatny, Twardowski prowadził wykłady z logiki i filozofii w Uniwersytecie Wiedeńskim. Ponieważ stanowisko to nie wiązało się ani z wynagrodzeniem, ani z prawami akademickimi, usilnie zabiegał o uzyskanie katedry w którymś z uniwersytetów galicyjskich. 18 października 1895 roku austriackie ministerstwo oświaty mianowało Twardowskiego na stanowisko profesora nadzwyczajnego filozofii w Uniwersytecie Lwowskim. Oficjalne objęcie katedry zwykło się datować na

Rozprawa uzyskała pochlebne recenzje od uczonych tej miary co: Alexius Meinong, Goswin K. Uphues, Hans Schmidkunz, Paul Natorp, Edmund Husserl, Josef Kreibig, Theodor Ziehen, Alois Höfler, Martin Anton Marty. Recenzje zamieszczono m.in. w czasopismach: „Mind“, „The Monist“, „Zeitschrift für Psychologie und Physiologie der Sinnesorgane“, „Revue Philosophique“, „Archiv für systematische Philosophie“, „Zeitschrift für Psychologie“. Utrzymana w Brentanowskim duchu i uzupełniająca refleksje mistrza rozprawa jest uznawana za najważniejszą pracę filozoficzną Twardowskiego (Woleński, 1985). 
15 listopada, ponieważ w tym dniu młody profesor wygłosił we Lwowie swój pierwszy wykład (Twardowski, 1997, 1).

1 października 1898 roku 32-letni Twardowski otrzymał nominację na stanowisko profesora zwyczajnego i odtąd - oprócz normalnej działalności naukowej i dydaktycznej - pełnił wiele odpowiedzialnych funkcji zarówno w uczelni, jak i poza nią. Był m.in.: rektorem w trudnych czasach I wojny światowej, prorektorem, dziekanem i prodziekanem Wydziału Filozoficznego, rzecznikiem kolegium profesorskiego, uniwersyteckim senatorem i rzeczoznawcą ministerialnym, inicjatorem i członkiem (także honorowym) licznych towarzystw naukowych, państwowych komisji egzaminacyjnych dla nauczycieli, komitetów organizacyjnych zjazdów i konferencji naukowych, członkiem Polskiej Akademii Umiejętności oraz rządowej Komisji Stabilizacyjnej, powołanej w roku 1919 w celu zorganizowania obsady profesorskiej Uniwersytetu Warszawskiego i innych polskich uczelni. To za jego sprawą została zreformowana (w latach 1908-1913) uniwersytecka kancelaria i unowocześniona (zdecentralizowana) struktura organizacyjna wydziałów i dziekanatów. To Twardowski opracował pierwszy regulamin studiów i unormował wpisy do indeksów. To on kierował pracami komitetu Powszechnych Wykładów Uniwersyteckich, a i sam - wygłaszając pogadanki i odczyty - propagował wiedzę filozoficzną i psychologiczną. Kierował również Towarzystwem Gimnazjum Żeńskiego (głównie ze względu na edukację swoich trzech córek), był też prezesem Towarzystwa Nauczycieli Szkół Wyższych oraz wiceprzewodniczącym Austriackiego Towarzystwa Szkoły Średniej. Wiadomo też, że przez całe życie był wierny swojej lwowskiej katedrze i nie opuścił jej mimo trzykrotnej nominacji na stanowiska w Uniwersytecie Warszawskim oraz mimo kilkakrotnych zaproszeń do pracy w ministerstwie oświaty (Twardowski, 1992, 1997, 1, 2). Ale to właśnie on przyczynił się do tego, iż po 1918 roku jeden z jego pierwszych uczniów - logik i matematyk Jan Łukasiewicz (1878-1956) - został najpierw szefem sekcji, a następnie ministrem szkolnictwa wyższego i na bieżąco konsultował z Twardowskim wszelkie decyzje personalne związane z obsadzaniem katedr filozofii, psychologii i pedagogiki w polskich uniwersytetach.

Bez wątpienia Twardowski był i jest jedną z najbardziej znanych i poważanych postaci w dziejach polskiej nauki. Mówiło się i mówi o nim: mistrz, nauczyciel filozofów, logików, matematyków i psychologów, twórca Szkoły Lwowsko-Warszawskiej, brzytwa metodologiczna. Zatem to oczywiste, że oprócz wielu prestiżowych nagród i należnych zaszczytów, w 1929 roku Twardowski otrzymał dyplom doktora honoris causa Uniwersytetu Warszawskiego. Wkrótce, bo w październiku 1932 roku - doktorat honoris causa Uniwersytetu Poznańskiego z rąk jego ówczesnego rektora Stefana Błachowskiego (1889-1962), psychologa i ucznia Twardowskiego.

10 maja 1929 roku, nękany cukrzycą, Twardowski podjął decyzję o przejściu w stan spoczynku. Jako że władze nie wyobrażały sobie uczelni bez tak 
zasłużonego profesora, decyzję tę starano się odwlec. Ostatecznie Twardowski rozstał się z Uniwersytetem Jana Kazimierza ${ }^{4} 30$ kwietnia 1930 roku. Tak napisał o tym wydarzeniu: „Ostatni raz dzisiaj byłem w swoim pokoju jako profesor zwyczajny w służbie czynnej. Toteż opuszczając pokój, zdjąłem kartkę z moim nazwiskiem pod tabliczką "Kierownictwo» (Seminarium filozoficznego). Od jutra nie będę już jego kierownikiem" (Twardowski, 1997, 2, s. 127). Jednak mimo to prowadził wykłady do $30 \mathrm{kwietnia} 1931$ roku, uczestniczył w posiedzeniach rad wydziału, a nawet zachował swój gabinet, ponieważ - zgodnie z decyzją prezydenta Rzeczpospolitej Polskiej - od 4 czerwca 1930 roku posiadał tytuł profesora honorowego, wiążący się z wieloma przywilejami.

Kazimierz Twardowski zmarł 11 lutego 1938 roku we Lwowie. Pogrzeb, który przyciągnął tłumy studentów, absolwentów i pracowników Uniwersytetu Jana Kazimierza oraz mieszkańców Lwowa, miał - zgodnie z wolą zmarłego - charakter świecki. Również zgodnie z jego wolą, do trumny włożono egzemplarz wyjątkowo cenionego przezeń przemówienia, zatytułowanego $O$ dostojeństwie uniwersytetu. Przemówienie, traktowane jako naukowy testament Twardowskiego, zawiera osobiste refleksje na temat zadań i roli uczelni oraz jej miejsca w systemie wartości uczonego. Zawiera także najbardziej bodaj trafną charakterystykę Twardowskiego w roli naukowca i dydaktyka:

Nauczyciel uniwersytecki jest przede wszystkim sługą prawdy obiektywnej, przedstawicielem jej i głosicielem wśród młodzieży i społeczeństwa. Służba to szczytna i niezmiernie zaszczytna, ale zarazem wymagająca nie tylko odpowiednich kwalifikacji intelektualnych i stosownej wiedzy fachowej, lecz także wielkiego hartu ducha i silnego charakteru. Kto się zaciąga pod sztandar nauki, musi się wyrzec wszystkiego, co mogłoby go zepchnąć z drogi sztandarem tym wskazywanej. (Twardowski, 1932/1992, s. $466-467)$

Zgodnie z testamentowym zapisem, Twardowski był „człowiekiem nauki, uczonym w najpełniejszym i najpiękniejszym tego wyrazu znaczeniu [...] głuchym na podszepty różnych ambicji”, który przez całe swoje życie potrafił „obronić się pokusie odgrywania jakiejkolwiek roli tam, gdzie wcale nie chodzi o prawdę, lecz o władzę, wpływy, o godności, o zaszczyty i tytuły albo po prostu o pieniądz!" (s. 468).

4 Na cześć założyciela uniwersytetu, króla Jana Kazimierza (1609-1672), zmianę nazwy (Universitas-Joannes-Casimiriano Leopoliensis) zatwierdził Naczelnik Państwa Józef Piłsudski (1867-1935), 8 listopada 1919 roku. 


\section{MisJA PSYCHOLOGICZNA}

Właściwie od momentu objęcia katedry w Uniwersytecie Lwowskim aż do końca życia Kazimierz Twardowski pracował zarówno na rzecz filozofii, jak i psychologii. Dlatego można go uznać za twórcę i filozoficznej, i psychologicznej szkoły naukowej. Szkoła filozoficzna, której historyczną i mery toryczną ciągłość gwarantowali uczniowie zatrudnieni po 1918 roku przeważnie w Uniwersytecie Warszawskim, została nazwana Szkołą Lwowsko-Warszawską (Woleński, 1985). Szkołę psychologiczną natomiast, której geneza i rozwój wiążą się wyłącznie ze Lwowem, można określić mianem Szkoły Lwowskiej. W jej dziejach dadzą się wyróżnić trzy okresy, w których Twardowski występował w roli mistrza: 1) od przełomu 1898/1899 do 1901 roku; 2) od roku 1902 do 1919; 3) od 1920 do 1939 roku (Rzepa, 1998, 2002).

\section{Pierwszy okres: 1898/1899-1901}

Na wykłady prowadzone przez Twardowskiego, który wniósł do Lwowa świeżość i oryginalność oraz powiew najnowszych osiągnięć nauki europejskiej, przychodziły tłumy. Jego daleka od romantyzmu i mesjanizmu inność oraz imponująca wiedza, skłonność do dyskutowania na dowolne tematy, czynienie siebie wzorcem rygorysty w spełnianiu obowiązków, postanowień i wymagań, gotowość do udzielania rad i wskazówek, żelazna logika i konsekwencja działania, zaangażowanie i chęć niesienia pomocy składały się na niezwykłą osobowość i sprawiły, że wokół Twardowskiego błyskawicznie utworzył się krąg zwolenników. Miejscem naukowych spotkań stało się powołane w 1897 roku pierwsze polskie seminarium filozoficzne, w którego pracach mogli brać udział studenci zainteresowani filozofią, psychologią, etyką i logikąa ${ }^{5}$ Wobec wyraźnego wzrostu zainteresowania psychologią Twardowski podjął decyzję o wygłoszeniu wykładów tematycznych. Pierwszy ich cykl, datowany na semestr zimowy roku akademickiego 1898/1899, dotyczył złudzeń wzrokowych, których występowanie każdy student mógł sprawdzić na sobie dzięki specjalnym tablicom, demonstrowanym przez mistrza. Nieco wcześniej Twardowski rozpoczął batalię o uzyskanie przez psychologię należnego jej miejsca w programach zajęć i w strukturach organizacyjnych uniwersytetu. Najpierw sprawił, że wykłady i ćwiczenia z psychologii weszły do programu studiów filozoficznych. Od 1897 roku gromadził aparaty, uznawane wówczas za niezbędne wyposażenie pracowni psychologicznej. W roku 1901 uzyskał zgodę władz galicyjskich na zagospodarowanie kilku pomieszczeń do eksperymentalnych badań z zakresu psychologii. Prowadzono je w wariancie fenomenologicznym, wykorzystywanym w pracowni kierowanej

5 Wymagania stawiane przez Twardowskiego powodowały, że seminaria kończyło około $30 \%$ spośród zapisujących się na nie studentów (Jadczak, 1997). 
przez Stumpfa, znacznie mniejszą wagę przykładając do powtarzania eksperymentalnych projektów z laboratorium Wundta (Witwicki, 1921, s. XIV).

Na ten okres przypada opublikowanie przez Twardowskiego pierwszych prac przygotowanych $\mathrm{w}$ języku polskim ${ }^{6}$ i zaznajamiających czytelników z przedmiotem, zadaniami i metodami psychologii oraz jej stosunkiem do innych nauk, zwłaszcza do filozofii i fizjologii (1897/1965, 1898/1965). W obszernych artykułach Twardowski poświęcił wiele miejsca kwestiom terminologicznym i definicyjnym. Wprowadził polskie nazwy i podał definicje tak kluczowych pojęć, jak m.in.: wrażenie, wyobrażenie, spostrzeganie, przedstawienie, abstrahowanie, dyspozycja psychiczna, akt psychiczny. W swoich pracach głosił, że przedmiotem psychologii jest życie psychiczne, na które składają się fakty (zjawiska, fenomeny) i dyspozycje psychiczne (np. wrażliwość, pamięć, wyobraźnia, inteligencja, wola). Bezpośrednim i oczywistym źródłem wiedzy o życiu psychicznym jest doświadczenie wewnętrzne - zawsze czyjeś i przez kogoś doświadczane dzięki introspekcji, możliwej za sprawą pamięci i wyobraźni. Psycholog zdobywający wiedzę o życiu psychicznym jest uprawniony zarówno do opisywania procesów i stanów zachodzących we własnym wnętrzu, jak i do rekonstruowania i interpretowania cudzego życia psychicznego, a na tej podstawie - do formułowania praw rządzących psyche (Twardowski, 1897; Witwicki, 1925; Rzepa, 2002).

Ten okres rozwoju lwowskiej psychologii wieńczy data 14 kwietnia 1901 roku, powiązana z sukcesem dydaktycznym Twardowskiego i naukowym Władysława Witwickiego (1978-1948), który właśnie tego dnia obronił pierwszą we Lwowie rozprawę doktorską z psychologii, pt. Analiza psychologiczna ambicji. Opublikowana w 1900 roku rozprawa zawiera podstawowe założenia teorii kratyzmu, pierwszej polskiej teorii psychologicznej. Witwicki uznał, że człowiek powodowany ambicją jest niezależny od innych ludzi i od okoliczności zewnętrznych, a tym samym doznaje stanów przyjemności z powodu górowania nad otoczeniem społecznym oraz sprawowania kontroli nad czynnikami sytuacyjnymi. Doświadcza przy tym poczucia mocy i siły moralnej. Dlatego utrwala się w nim ambitne pragnienie dominowania nad innymi, imponowania im i kierowania nimi. Uczyni wiele, aby ktoś inny nie stał się od niego lepszy, silniejszy, znaczniejszy, bardziej wartościowy, posiadający większą moc życiową. Zrobi wszystko, aby nie doznać uczuć przykrych, jak: pogarda, poniżenie, litość,

6 Istniały ku temu podstawy prawne; 4 lipca 1871 roku Uniwersytet Lwowski otrzymał bowiem (rok po Uniwersytecie Jagiellońskim) prawo do polskiego i ruskiego (ukraińskiego) języka wykładowego (Iłowiecki, 1981). W kwietniu 1879 roku język polski został uznany za urzędowy; nadal istniała możliwość zdawania egzaminów również po niemiecku i po rusku (ukraińsku), lecz jedynie za zgodą egzaminatora. Po trzech latach władze austriackie uznały za regułę wykłady w języku polskim, w języku ruskim zaś - za wyjątek. Ta decyzja rozogniła trwającą od dawna uniwersytecką „wojnę” polsko-ruską o narodowe wpływy i znaczenie. 
słabość, niemoc czy bezsilność z powodu niemożności pokonania jakiejkolwiek przeszkody (Witwicki, 1900; Markinówna, 1935).

\section{Drugi okres: 1902-1919}

To czas rozkwitu Szkoły i narodzin najważniejszych idei teoretycznych i metodologicznych. W 1904 roku Witwicki (znów jako pierwszy spośród uczniów Twardowskiego) uzyskał naukową samodzielność na podstawie rozprawy pt. Analiza psychologiczna objawów woli i podjąłstałą współpracęz Uniwersytetem Lwowskim jako docent prywatny. Wkrótce przedstawił rozwinięcie teorii kratyzmu, wykorzystując jej założenia do oryginalnej prezentacji genezy i typologii uczuć społecznych, zapowiadającej nowe obszary badań nad efektem pierwszego wrażenia i halo-efektem, źródłami komizmu oraz nad nawiązywaniem i utrzymywaniem relacji interpersonalnych (Witwicki, 1907, 1927).

W 1907 roku zakończyła się batalia Twardowskiego o regularne dotacje na funkcjonowanie lwowskiej pracowni psychologicznej, która stała się integralną jednostką uniwersytecką. Jednocześnie Twardowski systematycznie i skutecznie zabiegał o staże i stypendia naukowe dla swoich uczniów z myślą o korzystaniu przez nich $\mathrm{z}$ dorobku nauki europejskiej. Wiedział bowiem, że zdobyte za granicą doświadczenia, wiedza, nawyki i umiejętności zostaną z pożytkiem przeniesione do Lwowa. Dzięki tym staraniom wszyscy psychologowie, którzy wyszli spod jego skrzydeł, mogli uczęszczać na wykłady luminarzy ówczesnej psychologii oraz poznać organizację, metody i wyniki pracy słynnych laboratoriów psychologicznych. Kolejną bardzo ważną inicjatywą Twardowskiego było utworzenie w 1911 roku „Ruchu Filozoficznego” - czasopisma o profilu filozoficzno-psychologicznym, w którym zamieszczano: sprawozdania z zawartości czasopism zachodnich, recenzje książek oraz skróty lub omówienia odczytów, konferencji i referatów. Ponadto $\mathrm{z}$ racji rozległych kontaktów zagranicznych Twardowski był na bieżąco $\mathrm{z}$ najnowszymi publikacjami i albo tłumaczył je sam, albo wyznaczał któregoś z uczniów do pracy przekładowej. Zajmowali się nią m.in.: Witwicki, Mieczysław Kreutz (1893-1971), Zygmunt Zawirski (1882-1948), Izydora Dąmbska (1904-1983), Tadeusz Kotarbiński (1886-1981). $\mathrm{Z}$ inspiracji Twardowskiego przetłumaczono znane prace Williama Jamesa, Wilhelma Wundta, Gustava T. Fechnera, Aloisa Höflera, Auguste’a H. Forela czy Theodule'a A. Ribota.

W 1911 roku kolejny uczeń Twardowskiego, Stefan Baley (1885-1952), doktoryzował się pod jego kierunkiem, broniąc rozprawy pt. O potrzebie rekonstrukcji pojęcia psychologicznej podstawy uczuć (1907). W roku następnym, 1912, Twardowski zaprezentował oryginalną teorię czynności i wytworów, uzupełniającą wcześniejsze refleksje na temat struktury życia psychicznego. Wyszedł od prostego spostrzeżenia. Oto pewne wyrazy można zestawić w pary czasownikowo-rzeczownikowe, np. mówić-mowa, sądzić-sąd, myśleć-myśl, krzyczeć$k r z y k$. Pierwszy wyraz takiej pary oznacza czynność, drugi natomiast - wytwór 
tej czynności. Zarówno czynności, jak i wytwory można podzielić na fizyczne i psychiczne oraz trwałe i nietrwałe. Cecha trwałości przysługuje jedynie czynnościom i wytworom fizycznym. Wśród nich można wyróżnić kategorię czynności i wytworów psychofizycznych. O czynności psychofizycznej mówimy wówczas, gdy danej czynności fizycznej towarzyszy nietrwała czynność psychiczna, która wpływa na przebieg tej pierwszej, a tym samym na powstający (dzięki niej) wytwór psychofizyczny (np. list, przemówienie, melodia, rysunek, fotografia, wyraz mimiczny, wiersz, książka, obraz, pamiętnik itp., czyli każda oznaka i dokument psychologiczny). Wytwory psychofizyczne są obserwowalne i podlegają interpretacji, ponieważ ich obserwowanie lub/i interpretowanie wzbudza u osób dokonujących tych czynności określone wytwory psychiczne, analogiczne do towarzyszących autorowi tych wytworów podczas ich wytwarzania. Dlatego wytwory psychofizyczne są zewnętrznymi wyrazami (znakami) wytworów psychicznych. Ta odkryta przez Twardowskiego relacja wyrażania zapewnia możliwość odczytywania „zaklętego" w wytworze psychofizycznym wytworu psychicznego, który non omnis mortuus est, a tym samym stanowi podstawowy warunek psychologicznego interpretowania, które jawi się jako procedura metapodmiotowa, niezależna od miejsca i czasu jej przeprowadzania (Rzepa, 1993, 2002).

W następnym, 1913 roku Stefan Błachowski, który najpierw uczęszczał na prowadzone przez Twardowskiego i Witwickiego wykłady z filozofii i psychologii oraz studiował nauki przyrodnicze w Uniwersytecie Lwowskim, obronił w Getyndze pracę doktorską pt. Studien über den Binnenkontrast. Dysertację przygotował pod kierunkiem Georga Eliasa Müllera (1850-1934). Tuż po obronie powrócił do Lwowa i został asystentem Twardowskiego. Wkrótce, bo 12 grudnia 1917 roku, habilitował się w Uniwersytecie Lwowskim na podstawie pracy pt. Nastawienia i spostrzeżenia. Studium psychologiczne.

Ten okres rozwoju psychologii naukowej, zapoczątkowanej we Lwowie przez Twardowskiego, został zamknięty w roku 1919, kiedy to widoczne stały się efekty jego wzmożonej i blisko dwuletniej działalności wokół obsadzania katedr psychologii powołanych w pięciu uniwersyteckich miastach: Krakowie, Lwowie, Poznaniu, Warszawie i Wilnie. Najpierw 1 kwietnia 1919 roku profesorem psychologii w Uniwersytecie Warszawskim został mianowany Witwicki. Błachowski otrzymał taką nominację 16 lipca 1919 roku i objął Katedrę Psychologii w Uniwersytecie Poznańskim. Po długich zabiegach i po utworzeniu odrębnej Katedry Psychologii Wychowawczej w Uniwersytecie Warszawskim, 16 października 1928 roku objął ją Baley. Na wykłady z psychologii do Uniwersytetu im. Stefana Batorego w Wilnie dojeżdżał najpierw Błachowski, a następnie jego doktorant, ks. Mieczysław Dybowski (1885-1975). W 1935 roku kierownictwo wileńskiego Zakładu Psychologii objął Bohdan Zawadzki (1902-1966), uczeń i doktorant Witwickiego (Rzepa, 2000). 
Trzeba podkreślić, że wszyscy uczniowie Twardowskiego, w tym psychologowie, otrzymali w ramach prowadzonych przez niego zajęć dydaktycznych i podczas nieformalnych spotkań poświęconych dyskusjom na naukowe i życiowe tematy, niepowtarzalną „szkołę" metodologiczną, polegającą na ukształtowaniu umiejętności rzetelnego przekładania myśli na słowa i argumenty, dokonywania wnikliwych i logicznych opisów, rozumienia i interpretowania wszelkich wytworów pod kątem odkrywania głęboko w nich ukrytych myśli, uczuć i motywów postępowania.

\section{Trzeci okres: 1920-1939}

W tym czasie ze względu na rozproszenie uczniów Twardowskiego losy psychologicznej Szkoły Lwowskiej znacznie się skomplikowały. Z drugiej strony, dzięki oddaleniu od mistrza i pełnieniu funkcji kierowniczych w katedrach psychologii zyskali oni szansę na utworzenie własnych szkół naukowych. Tak się jednak nie stało i dlatego Szkoła Lwowska stanowi zamkniętą kartę w dziejach polskiej psychologii. Z tego powodu, choć ze smutkiem, można ją nazwać „szkołą zmarnowanych szans” (Rzepa, 1998, 2002).

W 1920 roku Twardowski doprowadził do utworzenia samodzielnego Zakładu Psychologii, którym kierował - rozglądając się za następcą - do 1928 roku. Jego zabiegi wokół tej sprawy były równie dyplomatyczne, co stanowcze. Zdawał sobie bowiem sprawę z nieskuteczności poszukiwania kandydatów poza Lwowem? Dlatego spowodował przyspieszenie pracy nad rozprawą habilitacyjną przez Mieczysława Kreutza, który uzyskał naukową samodzielność w grudniu 1927 roku. Umożliwiło to Twardowskiemu wystąpienie do ministerstwa o powierzenie Kreutzowi Katedry Psychologii. Decyzja o mianowaniu kolejnego ucznia Twardowskiego zastępcą profesora została podjęta 30 czerwca 1928 roku (Jadczak, 1997; Rzepa, 2014).

3 października 1928 [...]. Dr Mieczysław Kreutz, który od 1. bm. jest na mój wniosek zastępcą profesora psychologii i kierownikiem Zakładu psychologicznego, obejmuje też całkowite kierownictwo Zakładu, ja zaś przestaję się zajmować Zakładem tym pod każdym względem. Kończy się tedy długi okres mojej pracy [...]. Dr Kreutz szczęśliwszy ode mnie, otrzymuje w postaci gotowej to, co musiałem tworzyć w każdym szczególe krok za krokiem. Więc rzewnego doznaję uczucia $\mathrm{w}$ chwili rozstania się z tym

7 Po opuszczeniu Lwowa przez najstarszych uczniów-psychologów Twardowski podjął energiczne działania wokół przekształcenia Zakładu Psychologii w samodzielną katedrę, mimo że nie miał odpowiedniego kandydata na jej kierownika. Poszukiwał więc psychologa $\mathrm{z}$ habilitacją, choć jednocześnie, jako członek Komisji Stabilizacyjnej, doskonale wiedział o powojennych „wyścigach”, których celem było wychwytywanie samodzielnych pracowników nauki przez poszczególne - już polskie - uczelnie, opuszczone przez kadrę rosyjską, pruską i austriacką. W tej sytuacji podjął się niełatwego zadania, którego celem było umieszczenie na tym stanowisku Mieczysława Kreutza (Rzepa, 2014). 
moim tworem, któremu tyle trudu i czasu poświęcałem i w którym tyle nad młodzieżą naszą pracowałem. Aż dotąd spełniałem zadanie profesora psychologii obok zadań profesora filozofii. (Twardowski, 1997, 2, s. 44)

W ostatnim okresie Twardowski i Kreutz zdołali wykształcić grono wybitnych psychologów. Niestety, większość z nich zginęła podczas II wojny światowej, jak m.in. znakomicie zapowiadający się Walter Auerbach (?-1944) - uczeń również Witwickiego, Eugenia Blaustein (1905-1944) czy Leopold Blaustein (1905-1944), który studiował także pod kierunkiem Husserla i Stumpfa oraz brał udział w badaniach Maxa Wertheimera (1880-1943) na temat znajomości ludzi. Głównie spod skrzydeł Kreutza wyszedł Andrzej Lewicki (1910-1972), późniejszy organizator psychologii w Uniwersytecie im. Mikołaja Kopernika oraz założyciel pierwszej w Polsce Katedry Psychologii Klinicznej, w Uniwersytecie im. Adama Mickiewicza. Spod tych samych skrzydeł wyszedł również Tadeusz Tomaszewski (1910-2000), jedyny następca merytorycznych i organizacyjnych poczynań Twardowskiego ${ }^{8}$.

Ze zrozumiałych powodów historycznych okres ten zostaje zamknięty w roku 1939 - przez wybuch II wojny światowej. Przykro to stwierdzić, lecz lwowskie teorie psychologiczne nie zdobyły sobie rozgłosu ani w kraju, ani za granicą nie tylko ze względu na ich słaby „marketing” i językową barierę, lecz także z uwagi na brak zainteresowanych nimi kontynuatorów oraz niejasny opór samych twórców przed przełożeniem teoretycznych twierdzeń na „język” praktycznych zastosowań. Chociaż nietrudno z perspektywy czasowej oceniać to, „co się mogło stać inaczej”, jak powiedziałby z właściwą sobie sofisterią Witwicki, to jednak szkoda, że twórca psychologicznej Szkoły Lwowskiej oraz jego uczniowie nie zadbali o należyty rozwój własnych koncepcji psychologicznych. A już szczególnie szkoda, że najlepiej spośród nich rokujący Witwicki nie zdołał - wzorem Twardowskiego - założyć psychologicznej szkoły warszawskiej. Co prawda, usprawiedliwia go to, że do 1939 roku nie miał zbyt wiele czasu na wykonanie tak ważkiego zadania, po roku $1945^{9}$ nie miał zaś na to żadnych szans.

8 Tadeusz Tomaszewski jest najbardziej ceniony za to, że wychował kilka pokoleń psychologów oraz że jako uczeń Kreutza i Twardowskiego kontynuował założenia pedagogiczne i niektóre idee Szkoły Lwowsko-Warszawskiej w jej psychologicznym nurcie (Rzepa, 1997; Rzepa, Stachowski, 2011). Jest bowiem twórcą psychologicznej teorii czynności, zainicjowanej przez Twardowskiego (1912).

9 Nie miał na to szans nie tylko ze względu na swój wiek i stan zdrowia, lecz także z uwagi na wydarzenia historyczne, które na długie lata uzależniły Polskę od wpływów sowieckich. Chodzi przede wszystkim o rozprawienie się w 1947 roku przez komunistyczne władze z Polskim Stronnictwem Ludowym reprezentowanym przez Stanisława Mikołajczyka (19011966) oraz o obsadzenie w 1947 roku przez władze moskiewskie Bolesława Bieruta (1892-1956) na stanowisku prezydenta, a następnie - również za sprawą Józefa Stalina (1878-1953) - na stanowisku sekretarza generalnego (utworzonej w 1948 roku) Polskiej Zjednoczonej Partii Robotniczej. 


\section{Misja wojenna}

Chociaż psychologiczna misja Twardowskiego naznaczyła niemal całe jego życie, to nieporównanie krótsza misja wojenna, datowana od czerwca 1914 do września 1917 roku, kosztowała go wiele więcej wysiłku i zdrowia. Pełnił on wtedy bowiem trzykrotnie ${ }^{10}$ wyjątkową funkcję rektora czasu wojny - rektora, który wytrwale i konsekwentnie walczył o utrzymanie przez Uniwersytet Lwowski statusu uczelni polskiej, a jednocześnie niósł wszelką pomoc społeczności akademickiej.

Zgodnie z uczelnianym obyczajem, wybrani w czerwcu 1914 roku dziekani, prorektorzy i rektor mieli przejąć władzę 23 września. Twardowski wraz ze swoją rodziną spędzał wakacje jak zwykle w Poroninie. Tu zastał go wybuch wojny. Ponieważ wojska rosyjskie już w nocy z 3 na 4 września zajęły Lwów, należało podjąć decyzję o dalszym postępowaniu. W tym celu zwołano naradę, która odbyła się w wilii „Sienkiewiczówka”, zajmowanej przez historyka sztuki Jana Bołoza-Antoniewicza (1858-1922). Uczestniczyli w niej członkowie Senatu Uniwersytetu Lwowskiego przebywający w Zakopanem i w okolicznych miejscowościach. Ustalono, że Twardowski powinien wyjechać do Wiednia. Tak też się stało. Twardowski wraz z rodziną opuścił Poronin 17 września i po dwóch dniach przybył do stolicy Austro-Węgier. Tam, wedle zwyczaju, 23 września objął formalnie urząd rektora Uniwersytetu Lwowskiego, który pełnił przez trzy wojenne lata, w tym w Wiedniu - do 2 lipca 1915 roku.

W okresie wiedeńskim praca rektora Twardowskiego polegała na podejmowaniu nietypowych dla piastowanego stanowiska decyzji i działań, gdyż górę wzięły kwestie organizacyjne. Sprawy dydaktyczne i naukowe znalazły się na marginesie. Rektorska praca w warunkach wojennych polegała bowiem na docieraniu do emigrantów: wykładowców uniwersyteckich i studentów oraz na organizowaniu im codziennego życia i poszukiwaniu dla nich źródeł utrzymania. Twardowski roztoczył uważną opiekę nad młodzieżą akademicką, zwłaszcza nad zbiegami spod rosyjskiej okupacji, nad studentami niezdolnymi do służby wojskowej i spragnionymi kontynuowania rozpoczętych przed wojną studiów, choć tymczasem zagrożonymi głodem, brakiem pracy, dachu nad głową czy ciepłej odzieży. Twardowski z prawdziwie rektorską godnością potrafił na tego typu cele zdobywać pieniądze $\mathrm{z}$ różnych instytucji i komitetów oraz od osób prywatnych. Zarówno zachęcał profesorów przebywających na emigracji, jak i sam wygłaszał pogadanki i odczyty oraz urządzał zbiórki uliczne. Wkrótce powołał do życia Fundusz Zapomogowy Polskiej Młodzieży Akademickiej i jednocześnie utworzył Dom Akademicki „dla słuchaczów szkół najwyższych z Galicji i Bukowiny", w którym tylko w 1915 roku znalazło schronienie i wyżywienie oraz możliwość pracy 332 polskich studentów, w tym 177 osób ze Lwowa (Jadczak, 1991). Za zdobyte fundusze Twardowski zlecał zakup produktów

10 Ówcześni rektorzy byli wybierani na roczną kadencję. 
do kuchni akademickiej, rozdzielał bony żywnościowe i dotacje odzieżowe, przyznawał zasiłki i zapomogi, organizował pomoc medyczną. Dzięki przynależności do Komitetu Pomocy dla Uchodźców z Galicji i Bukowiny pomagał emigrantom w przypadku problemów paszportowych i trudności w znalezieniu pracy, reklamował młodych uczonych i studentów ze służby wojskowej i dbał o możliwość kontynuacji przerwanych studiów. W tym celu - przy współpracy $z$ lwowskimi i wiedeńskimi profesorami - organizował dodatkowe kursy oraz przeprowadzał oficjalnie uznawane egzaminy i rygoroza, zwłaszcza w zakresie prawa i filozofii.

W skąpych notatkach Twardowskiego (1997, 1), datowanych na luty i marzec 1915 roku, znajdują się informacje o opisanych powyżej działaniach organizacyjnych: od ukierunkowanych na zdobycie funduszy wizyt w ministerstwach i innych urzędach czy u majętnych znajomych, przez zamawianie łóżek, sienników, materacy i żywności oraz negocjacje w sprawach uczelnianych zajęć i egzaminów, po udział w debatach na temat dalszych losów Europy i Polski. A o tym, jak nader poważnie, z godnością i odpowiednim dystansem traktował Twardowski siebie w roli rektora, świadczy dobitnie to, iż jedynie w okresie pełnienia tej funkcji używał w odniesieniu do siebie samego jej nazwy, zapisywanej w Dzienniku wielką literą. Przykładowo: „6. luty [1915]: Deputacja Rektora i dziekanów u Ministra galicyjskiego Dra Zdzisława Morawskiego ${ }^{11}$ z życzeniami [...]” (s. 15).

20 czerwca 1915 roku wojska rosyjskie opuściły Lwów. Twardowski natychmiast podjął decyzję o powrocie i 5 lipca przybył do swojego miasta (Jadczak, 1991). Od razu przystąpił do odbudowy życia uniwersyteckiego, działając w ciągle niepewnych warunkach wojennych, pod ustawiczną groźbą braku dosłownie wszystkiego oraz pod presją nagłej ewakuacji. Dobrze wiedział, że jeśli w tych okolicznościach zamierza pełnić funkcję rektora w taki sposób, aby zachować autonomię uczelni, odbudować życie naukowe, prowadzić dydaktykę, bronić pracowników i studentów przed szykanami władz i przed zapędami różnych komitetów i organizacji politycznych, to powinien kierować się rozwagą i spokojem, zachować stoicką postawę oraz stosować przede wszystkim dyplomację. Dlatego z właściwym sobie dostojeństwem i godnością - jak w Wiedniu, tak i we Lwowie - Twardowski zabiegał o zapewnienie odpowiednich warunków socjalnych dla powracających z wojska pracowników akademickich i studentów. Pomagał rodzinom w staraniach o wydobycie z niewoli zakładników i jeńców związanych z Uniwersytetem Lwowskim. Młodzieży powracającej z emigracji udzielał urlopów na przygotowanie się do zaległych egzaminów. I nie krył, że podczas rozwiązywania szczególnie trudnych problemów korzystał z wydatnej pomocy brata, Juliusza Twardowskiego (1874-1945), który pierwotnie

11 Zdzisław Morawski (1859-1928), prawnik, radca ministerialny w Ministerstwie dla Galicji, od 30 stycznia 1915 roku minister ds. Galicji. 
był zastępcą ministra, a od 23 czerwca 1917 do 25 lipca 1918 roku kierował Ministerstwem dla Galicji przy cesarskim rządzie (Twardowski, 1997, 1).

Wzorując się na sprawdzonych w Wiedniu metodach postępowania, Twardowski - w porozumieniu z Polskim Archiwum Wojennym - zainicjował akcję „odczytów wojennych”, realizowaną przez lwowskich profesorów. Jej celem było zgromadzenie funduszy „na polskie dokumenty i pamiątki wojenne". Ponadto powołał Senacką Komisję Opieki nad Młodzieżą Akademicką, której główne zadania polegały na zapewnieniu studentom opieki zdrowotnej i zapomogowej oraz na rozszerzeniu oferty domów studenckich i kuchni akademickich. Przeniósł także z Wiednia do Lwowa i tu przez kilka lat skutecznie pomnażał Fundusz Zapomogowy Dla Młodzieży Akademickiej, którym zarządzał do 1920 roku. Zebrane środki (w porozumieniu ze studencką organizacją Bratnia Pomoc) przeznaczano na wspieranie zdolnych i ubogich studentów, w tym na ich leczenie i pobyt w uzdrowiskach. Od jesieni 1915 roku z finansów Funduszu utrzymywano personel i kupowano żywność do kuchni studenckiej w Domu Akademickim im. Potockiego. Warto odnotować, że organizacją pracy w kuchni kierowały na zasadzie dobrowolnych dyżurów żony profesorów (Twardowski, 1997, 1).

Mimo stoickiej postawy, polegającej m.in. na zachowywaniu odpowiedniego dystansu wobec polityki (Rzepa, 1993a), Twardowski siłą rzeczy nieustannie się o nią ocierał. Wszak stanowisko rektora wymagało reprezentowania społeczności uczelnianej wobec wojskowych, cywilnych i kościelnych władz austriackich i galicyjskich. Tak więc Twardowski uczestniczył w nabożeństwach dziękczynnych i żałobnych (np. w mszach za namiestnika Galicji Andrzeja Potockiego ${ }^{12}$ ), w pogrzebach (głównie poległych na wojnie pracowników i studentów Uniwersytetu Lwowskiego), audiencjach u władz, w przedstawieniach i akademiach na rzecz rozmaitych funduszy (np. dla wdów i sierot po żołnierzach austriackich, ale i po legionistach Józefa Piłsudskiego), w zebraniach ciał uniwersyteckich, organizacji studenckich i pozauniwersyteckich. Jednocześnie przyjmował liczne delegacje, przybywające ze sprawami zarówno pomniejszej rangi, jak i wagi państwowej. Przykładowo: „18 marca, sobota [1916]: Brygadier Piłsudski składa wizytę Rektorowi w Uniwersytecie w towarzystwie adiutanta Dra Długoszowskiego. Wieczór w Kasynie Miejskim raut na cześć Piłsudskiego. Obecny także Rektor" (Twardowski, 1997, 1, s. 21).

Jako członek rozmaitych komitetów, Twardowski brał udział w krajowym projekcie opieki nad inwalidami, w uroczystym świętowaniu rocznic (np. powstania styczniowego czy Konstytucji 3 Maja), w odsłonięciach pomników

12 Andrzej Kazimierz Potocki (1861-1908), oficer ordynansowy cesarza Franciszka Józefa, ówcześnie bardzo znany polityk, wskutek nieporozumień między Klubem Ukraińskim i Kołem Polskim (m.in. w sprawie Uniwersytetu Lwowskiego) został zastrzelony 12 kwietnia przez studenta filozofii, Ukraińca Mirosława Siczyńskiego (1887-1979). 
(np. Żelaznego Rycerza Miasta Lwowa), w zbiórkach datków i podarków dla żołnierzy i ich rodzin. Rozstrzygał konflikty i antagonizmy narodowościowe, łagodził wewnątrzuczelniane spory i pacyfikował - poprzez „zawieszanie wykładów” - przejawy nadmiernego „rozpolitykowania” studentów i części profesorów „wywierających na młodzież wpływ podkopujący jej zaufanie do Senatu Akademickiego i Rektora”. Powodów po temu nie brakowało. Burzono się bowiem tak ze względu na "brak formalnego stanowiska”, jak i z uwagi na niedostateczne „zamanifestowanie solidarności” czy to z działającym w Wiedniu Kołem Polskim ${ }^{13}$, czy ze strajkującymi w Warszawie studentami w sprawie projektu „ogólnej polityki polskiej”, a też z powodu „dokonanego na Piłsudskim gwałcie i mieszaniu się obcego mocarstwa w nasze sprawy wewnętrzne"14. W najbardziej drażliwych kwestiach Twardowski (1997, 1, s. 29-40) postępował zgodnie z postawą stoicką i podejmował dyplomatyczne zabiegi, których celem było niedopuszczenie „do przewagi pajdokracji w sojuszu z demagogią”. Uważał bowiem, że: „zasada wszystko albo nic prowadzi często do nic aniżeli do wszystko". Zasadę tę odnosił głównie do polityki i zajmowania się nią, a nie sprawami uczelni przez część kadry uniwersyteckiej, stojącej w opozycji wobec podejmowanych przez niego działań i wobec jego apolitycznej postawy:

Jeszcze bardziej stanowczo skarciłem tych [...], którzy zaraz każdego, kto jest odmiennego zdania, odsądzają od polskości. Rzekłem, że to włażenie ludziom na charakter i podejrzewanie ich o Bóg wie co, bo nie są za polityką krzyków, manifestacji i frazesów, lecz za polityką realnej pracy, dowodzi słabości stanowiska tamtych. Kto ma argumenty, nie potrzebuje posługiwać się wyzwiskami. (Twardowski, 1997, 1, s. 45)

Twardowski zaktywizował swoje zabiegi dyplomatyczne wówczas, gdy ukraińscy politycy i uniwersyteccy pracownicy narodowości ukraińskiej podjęli kolejną i zgrabnie skonstruowaną intrygę, której celem było doprowadzenie do utrakwizacji uczelni ${ }^{15}$. Spór o Uniwersytet Lwowski, który Polacy uznawali za swój „skarb narodowy”, miał trudną, wieloletnią historię. Od połowy

13 Koło Polskie jako ugrupowanie liczące 50-70 posłów z Galicji, wchodzących w skład parlamentu austriackiego, powstało w latach 60. XIX wieku. Od 1879 roku wchodziło w skład większości rządowej i miało swoich przedstawicieli w gabinecie austriackim. W czasie I wojny światowej odegrało ważną rolę w zakresie niesienia pomocy uchodźcom z Galicji i Bukowiny, a od 1917 roku zajmowało jednoznaczne stanowisko w sprawie pełnej niepodległości Polski. Chodziło o aresztowanie (14 lipca 1917 roku) i osadzenie w magdeburskiej twierdzy Józefa Piłsudskiego po odmowie złożenia przezeń przysięgi na wierność cesarzom Niemiec i Austro-Węgier.

15 Utrakwizacja oznacza zatwierdzoną przez władze i formalnie obowiązującą dwujęzyczność, głównie w instytucjach państwowych i w szkolnictwie. W tym przypadku chodziło o dwujęzyczność polsko-ukraińską w Uniwersytecie Lwowskim. 
XIX wieku ${ }^{16}$ bowiem „ogół polski obawiał się, żeby Rusini ${ }^{17}$ nie zechcieli przemienić stopniowo polskiego Uniwersytetu we Lwowie na ruski; stąd też niechętne, podejrzliwe odnoszenie się do nowych ruskich katedr i genetyczno-zazdrosne strzeżenie wyłączności języka polskiego we wszelkich czynnościach uniwersytetu" (Koneczny, 1906, s. 225, za: Ryba, 2014; Polak, 2011). Jednocześnie Polacy nie mieli nic przeciwko temu, aby Rusini utworzyli własną uczelnię, z ruskim językiem wykładowym. Jednakże ci woleli inne rozwiązanie i odrzucali argumenty o polskiej genezie i tradycji Uniwersytetu Lwowskiego, o znakomitej polskiej kadrze i studentach, a nawet o podatkach i darowiznach przeznaczanych przez Polaków na tę uczelnię. Ukraińskie dzienniki, które od dawna prowadziły napastliwą politykę wobec jakichkolwiek posunięć podkreślających polski charakter, tradycję i genezę uczelni, wyraźnie uaktywniły się w czasie wojny. „20 stycznia [1916], czwartek: 255. rocznica fundacji Uniwersytetu przez Jana Kazimierza. Rektor ogłosił stosowne przypomnienie tej rocznicy na czarnej tablicy. Lwowskie dzienniki [...] dały artykuły okolicznościowe. Z tej racji „Diło” z 21 stycznia 1916 w numerze 19/8918 napadło na Rektora” (Twardowski, 1997, 1, s. 17). Tym samym Twardowski nie po raz pierwszy się przekonał, że „prasa ruska czyha na wszelkie sposobności, by przeciwstawiać «nielojalny» obchód Jana Kazimierza lojalnemu stwierdzeniu, że Uniwersytet jest fundacją cesarzy austriackich". W tej sprawie jego stanowisko było niezmienne i oparte na przekonaniu o jedynie słusznym „rozwiązaniu kwestii narodowościowej w naszym kraju” przez zachowanie „narodowościowej autonomii” organizacji, stowarzyszeń i szkolnictwa (Twardowski, 1997, 1, s. 36-37).

W sierpniu 1917 roku środowisko ukraińskie przypuściło prawdziwy ,atak” na polskość Uniwersytetu. W tym celu wystarano się o audiencję u generała-gubernatora Lwowa, Karla G. Huyna (1857-1938), podczas której usiłowano go przekonać o wierności i oddaniu Ukraińców w odróżnieniu od przewrotności Polaków. Twardowski dowiedział się o tym bezpośrednio od Huyna podczas długiej rozmowy w cztery oczy i tak zreferował jego wypowiedź:

Pragnie dla nas zachowania naszego stanowiska w kraju, które się nam należy [...] i jest przeciwny wszelkim tendencjom podziału kraju. Wszak w Galicji wschodniej Polacy tworzą bardzo silną mniejszość i są elementem gospodarczo i kulturalnie dominującym. Ale ze strony zwolenników podziału kraju spotyka się z takim argumentem: „Więc Pan chce ludność

16 Wówczas Austriacy - w myśl zasady divide et impera - przyznali Rusinom uprzywilejowane stanowisko, wprowadzając wykłady w języku ruskim (ukraińskim) na wydziałach teologicznym i prawniczym. Ponadto Polacy uzyskali pozwolenie na utworzenie katedry języka polskiego w 1856 roku, podczas gdy katedra literatury ruskiej (ukraińskiej) istniała już od roku 1849.

17 W nomenklaturze polskiej i rosyjskiej termin Rusini był wówczas powszechnie używany w odniesieniu do Ukraińców. 
niepolską Galicji wschodniej, która wiernie chce stać przy Austrii, poddać pod rządy i wpływ polityczny Polaków, którzy [...] wyraźnie wypowiedzieli państwu austriackiemu posłuszeństwo?”. A na taki argument, powiedział Huyn, nie mam odpowiedzi. (Twardowski, 1997, 1, s. 44)

W tej trudnej sytuacji Twardowski wykorzystał dostępne kanały dyplomatyczne, włącznie z braterskim, po to, by Uniwersytet zachował swój odwieczny, polski charakter. Tak o tej zasłudze Twardowskiego napisał Witwicki:

Nie mieszał się do polityki i nie kandydował do ciał ustawodawczych [...]. Potrafił za swego rektorstwa uratować Uniwersytet Lwowski przed utrakwizacją ze strony rządu austriackiego. To był jego czyn polityczny. [...] Żadne stronnictwo polityczne nie mogło o nim powiedzieć: „to nasz człowiek”. Ale musi to o nim powiedzieć każdy oświecony Polak. $(1938$, s. 1)

Mimo tylu działań wręcz nie do przecenienia ze względu na trudności związane z okolicznościami wojennymi, Twardowski nieprędko doczekał się słów uznania czy należnych podziękowań. Zaważył na tym pewien splot wydarzeń, który przyniósł mu wiele nieprzyjemności i zajadłej krytyki. Punktem wyjścia stał się zatwierdzony przez Senat Uniwersytetu Lwowskiego wniosek „grona profesorów Wydziału Filozoficznego” o nadanie „Jego Cesarskiej i Królewskiej Wysokości Arcyksięciu Fryderykowi ${ }^{18}$ godności Doktora filozofii honoris causa" (Twardowski, 1997, 1, s. 20). Wręczenie dyplomu - którego to aktu dokonał rektor Twardowski - odbyło się w Cieszynie 10 maja 1916 roku. Chociaż w okolicznościowym przemówieniu Twardowski z całą mocą podkreślił uwarunkowane tradycją narodową prawa Polaków do Uniwersytetu, to bardziej zapamiętano mu, że o przyszłości uczelni mówił z nadzieją i wiarą w „cesarską osłonę i opiekę” (s. 23).

W czerwcu 1917 roku Twardowski dowiedział się od brata Juliusza, że został przewidziany do cesarskiego odznaczenia. Natychmiast zareagował negatywnie i w liście wysłanym przez posłańca prosił brata, aby odstąpiono od tego zamiaru. Jednak stało się inaczej. I tak 26 czerwca 1917 roku prasa doniosła o tym, że Twardowski - jakoby w zamian za uhonorowanie arcyksięcia Fryderyka doktoratem z filozofii - otrzymał Krzyż Komandorski Orderu Franciszka Józefa $z$ dekoracją wojenną. Po tym wydarzeniu, zjadliwie skomentowanym w prasie, środowisko lwowskie powszechnie uznało, że Twardowskiemu należy przypisać miano austrofila. Odtąd stał się „złym Polakiem, zdrajcą ojczyzny”. 25 lipca 1917 roku odnotował z goryczą:

na tej samej stronie „Kuriera Lwowskiego” znajduje się notatka [...]: „Z powodu wysokiego odznaczenia Jego Magnificencji Rektora Twardowskiego

18 Fryderyk Maria Albrecht Wilhelm Karol Habsburg (1856-1936), ostatni książę cieszyński, naczelny dowódca cesarsko-królewskiej obrony terytorialnej, generalny inspektor armii Austro-Węgier, a w latach 1914-1916 jej głównodowodzący i marszałek polny. Oprócz lwowskiego, uzyskał honorowe doktoraty na uniwersytetach w Wiedniu, Pradze i Brnie. 
za jego patriotyczną działalność - młodzież polska akademicka składa 45 koron”. Tak brzmi notatka. - Kto pamięta uzasadnienie nadania mi orderu [...] zrozumie to ukłucie szpilką, które mi zadała młodzież anonimowo [...]. (s. 43)

Przy dokonywaniu tej stygmatyzacji zapomniano o licznych i rzeczywistych zasługach Twardowskiego, nie zwrócono też uwagi na to, że za pomoc udzielaną w czasie wojny osobom jej potrzebującym otrzymał honorową odznakę Czerwonego Krzyża II Klasy z dekoracją wojenną. Większą sensacją było powielanie przez długie lata „poufnej” informacji o austrofilskiej działalności Twardowskiego w czasie I wojny światowej. Nic więc dziwnego, że w jego dzienniku rzadko można znaleźć takie słowa:

Tam spotkanie z Prof. Włodzimierzem Łukasiewiczem ${ }^{19}$, od którego usłyszałem wiele ciepłych i serdecznych słów a’propos mej działalności rektorskiej. Ma on pełne zrozumienie dla mego trudnego położenia, a zarazem bezwzględne uznanie dla kierunku, w którym jako Rektor działam, nie dając się wciągnąć w żadną politykę pozauniwersytecką. (Twardowski, 1997, 1, s. 37-38)

O wiele częściej natomiast Twardowski dowiadywał się o sobie takich informacji: „Zarzucano mu [Twardowskiemu]:1) że jest masonem, należącym do lóż masońskich (sic!) i 2) że jest ateusz i [...] szkodził kościołowi” (s. 130).

Po pierwszej powojennej inauguracji roku akademickiego, 25 października 1919 roku, w „zmartwychwstałej Polsce” Twardowski z goryczą napisał:

część sprawozdania tyczącą się mego triennium (1914-17) dostarczyłem $\mathrm{mu}$ [prorektorowi Waisowi ${ }^{20}$ ] ja sam na jego prośbę [...]. O sobie nic w nim nie mówiłem; zamiast mówić „Rektor zrobił to i owo”, pisałem zawsze „Władze akademickie zrobiły to i owo”. Nie wspomniałem też nigdzie o fakcie mego trzykrotnego z urzędu wyboru ani o tym, że, gdy ustępowałem, Senat Akademicki uroczyście mnie pożegnał i pierścieniem obdarzył. I ks. Wais o tym nie wspomniał. [...] nie wspomniał ani słówkiem o moim bądź co bądź wyjątkowym rektoracie. Niczego innego się nie spodziewałem [...]. (1997, 1, s. 135)

W tym miejscu należy odnotować, że ten wyjątkowo trudny okres pełnienia wojennej misji przez rektora Twardowskiego doceniono dopiero w przemówieniach pośmiertnych. Na domiar złego nie było widać końca sprawy doktoratu honorowego dla arcyksięcia Fryderyka Habsburga. Otóż 6 grudnia 1918 roku

19 Włodzimierz Łukasiewicz (1860-1924), profesor dermatologii i wenerologii, wykładowca uniwersytecki w Innsbrucku i we Lwowie, członek Najwyższej Austriackiej Rady Zdrowia. 
członkowie Wydziału Filozoficznego uchwalili wniosek o „skasowaniu udzielonego swego czasu Arcyksięciu Fryderykowi doktoratu honorowego" (1997, 1, s. 74). W tej sprawie 17 marca 1919 roku obradowała senacka komisja, która wezwała Twardowskiego do przedstawienia genezy i historii tego doktoratu:

Chociaż pachniało mi to nieco „przesłuchaniem”, postanowiłem uczynić zadość życzeniom Komisji, więc przez dwie i pół godziny podawałem dokładne informacje o całym tle sprawy, o jej genezie, przebiegu i moim w tym udziale. Po raz pierwszy wyjawiłem sprawę [...] żądania, abym zrezygnował z Rektoratu [...], donosy, które szły stąd na mnie do Wiednia itp. Przedstawiłem także powody, dla których uważałem za rzecz niemożliwą przeszkodzić dojścia do skutku tego doktoratu, chociaż projektem tym wcale się nie zachwycałem. (1997, 1, s. 92-93)

23 maja podczas rady Wydziału Filozoficznego odczytano „pismo Senatu Akademickiego w sprawie kasacji doktoratu honorowego b. arcyksięcia Fryderyka. Pismo to wywołało u wszystkich członków Fakultetu jak najgorsze wrażenie" (Twardowski, 1997, 1, s. 104) i dlatego uchwalono powołanie specjalnej komisji w celu ułożenia projektu nowego pisma zamiast negatywnie przyjętego dokumentu, który sformułowali senatorzy. 30 maja zaakceptowano treść nowego pisma skonstruowanego przez tę komisję oraz uchwalono, że delegacja wydziałowa „ma skłonić Senat do reasumpcji uchwały jego i cofnięcia pisma owego. Jeśli Senat na to się zgodzi do 7. czerwca 1919, ma odejść do Senatu i Ministerstwa pismo Fakultetu, dzisiaj uchwalone" (s. 106). 12 czerwca ponownie odbyła się dyskusja członków rady Wydziału Filozoficznego w sprawie zatargu z senatem, który nie cofnął swojego pierwotnego pisma. Ostatecznie przegłosowano ważność uchwały z 30 maja i tym samym dziekan „musiał uchwalone wówczas pismo wysłać do Ministerstwa i do Senatu Akademickiego" (s. 108). Zamknięcie nieszczęsnego ciągu wydarzeń nastąpiło dzięki ówczesnemu rektorowi, profesorowi prawa, Alfredowi Halbanowi (1865-1926), który 25 listopada 1919 roku zaprosił Twardowskiego na konferencję: „omawia ze mną kwestię sfinalizowania sprawy doktoratu honorowego b. Arcyksięcia Fryderyka. Radzę sprawy tej w ogóle nie tykać, natomiast co do dokonanego swego czasu przez Senat Akademicki przekroczenia jego kompetencji, wywołać cofającą uchwałę Senatu Akademickiego" (s. 139). I tak się stało.

21 września 1917 roku Twardowski po raz ostatni przewodniczył posiedzeniu Senatu Uniwersytetu Lwowskiego.

Trwało od piątej do dziewiątej. Na zakończenie Prorektor Jaszowski ${ }^{21}$ w ciepłych słowach do mnie przemówił imieniem Senatu Akademickiego

21 Błażej Jaszowski (1856-1921), ksiądz, profesor prawa kościelnego, rektor Uniwersytetu Lwowskiego w latach 1911-1912. 
i na zakończenie wręczył mi stalowy pierścień od członków Senatu Akademickiego $\mathrm{z}$ herbem uniwersyteckim i napisem wewnątrz: „Rektorowi lat 1914-1917. Senat”. W dłuższym przemówieniu podziękowałem. (Twardowski, 1997, 1, s. 49)

Dopiero złożenie przez Twardowskiego funkcji na ręce nowego rektora, ks. Kazimierza Waisa, a przede wszystkim fakt odzyskania niepodległości przez Polskę oraz polskość Lwowa i Uniwersytetu, stworzyły bezpieczne i dogodne warunki do podjęcia przerwanej aktywności naukowo-dydaktycznej i działalności organizacyjnej oraz umożliwiły kontynuowanie życiowej misji, polegającej na rozwijaniu szkoły naukowej, znanej dziś jako Szkoła Lwowsko-Warszawska.

Na zakończenie warto podkreślić, że trzy najważniejsze nurty naukowe - filozoficzny, logiczny i psychologiczny - zainicjowane we Lwowie przez Kazimierza Twardowskiego łączy ideologia scjentystyczna, na którą składają się: racjonalizm $\mathrm{w}$ sensie antyirracjonalizmu, wiara w siłę nauki i rolę rozumu, postulat jasności i wyraźności myśli w słowie wyrażanych oraz intelektualizm (Woleński, 1985; Jadczak, 1995; Rzepa, 1998).

Nad ówcześnie dominującą psychologię eksperymentalną psychologowie ze Szkoły Twardowskiego przedkładali psychologię deskryptywną, uznawaną za jedno z podstawowych źródeł psychologii humanistycznej. Uprawianej przez siebie psychologii nadali dzięki temu humanistyczne rysy, akcentowali bowiem fenomenologiczne podstawy poznania i jego podmiotowy, niepowtarzalny charakter. Podkreślali funkcjonalne właściwości psyche oraz uznawali różnice między świadomością i psychicznością, a także zajmowali interakcyjną postawę wobec relacji dusza-ciało. Mimo że cenili introspekcję jako metodę psychologicznego poznania, to w celu obiektywizacji tego procesu wykorzystywali również psychologiczne analizy i interpretacje obserwowalnych (trwałych i nietrwałych) przejawów życia psychicznego, podkreślając wartość wiedzy i intuicji w badaniu psychologicznym. Psychologię o lwowskiej genezie wyróżnia ponadto - uzasadniony wymogiem holistycznego podejścia do człowieka - efektywny sprzeciw wobec ówczesnej „testomanii”. Wyróżnia ją też specyficzny styl pisarstwa naukowego, cechujący się jasnym i wyraźnym, a jednocześnie eleganckim językiem oraz barwnymi przykładami wywodzącymi się ze skrupulatnie gromadzonych „obserwacji życiowych”. Dlatego Kazimierzowi Twardowskiemu jako twórcy psychologicznej Szkoły Lwowskiej oraz jego uczniom-psychologom należy przypisać pierwszeństwo $\mathrm{w}$ formowaniu paradygmatu humanistycznego w polskiej psychologii. 


\section{Bibliogr Afia}

Ajdukiewicz, K. (1959). Pozanaukowa działalność Kazimierza Twardowskiego. Ruch Filozoficzny, XIX, 1-2, 29-35.

Baley, S. (1907). O potrzebie rekonstrukcji pojęcia psychologicznej podstawy uczuć. Lwów: Polskie Towarzystwo Filozoficzne.

Błachowski, S. (1917). Nastawienia i spostrzeżenia. Studium psychologiczne. Lwów: Polskie Towarzystwo Filozoficzne.

Brentano, F. (1874/1999). Psychologia z empirycznego punktu widzenia. Warszawa: Wydawnictwo Naukowe PWN.

Iłowiecki, M. (1981). Dzieje nauki polskiej. Warszawa: Wydawnictwo Interpress. Ingarden, R. (1963). Działalność naukowa Kazimierza Twardowskiego. W:

R. Ingarden, $Z$ badań nad filozofia współczesna. Warszawa: Państwowe Wydawnictwo Naukowe.

Jadczak, R. (1991). Kazimierz Twardowski. Twórca szkoły lwowsko-warszawskiej.

Toruń: Wydawnictwo Adam Marszałek.

Jadczak, R. (1992). Wstęp. W: K. Twardowski, Wybór pism psychologicznych

i pedagogicznych. Warszawa: Wydawnictwa Szkolne i Pedagogiczne.

Jadczak, R. (1995). Powstanie filozofii analitycznej w Polsce. Toruń: Wydawnictwo Adam Marszałek.

Jadczak, R. (1997). Mistrz i jego uczniowie. Warszawa: Wydawnictwo Scholar. Koneczny, F. (1906). Swary uniwersyteckie we Lwowie. Świat Słowiański, 2(4), 225-233.

Markinówna, E. (1935). Psychologia dążenia do mocy. Zestawienie poglądów Witwickiego i Adlera. Kwartalnik Psychologiczny, 7, 329-340.

Pietrasiński, Z. (2015). Dziennik komputerowy z [...]. Lublin: Wydawnictwo Uniwersytetu Marii Skłodowskiej-Curie.

Polak, R. (2011). Kwestia ukraińska w publicystyce politycznej Feliksa Konecznego. Pobrane z: http://realitas.pl/Archiwum/2011/RP2VII.html\#_ftn; dostęp 23 czerwca 2015

Ryba, M. (2014). Feliks Koneczny: lekcja polityki. Pobrane z: http://realitas.pl/ SwiatoOglad/2014/MR7V.html; dostęp 23 czerwca 2015

Rzepa, T. (1993). Psychology as seen by Kazimierz Twardowski. W: R. Stachowski (red.), Roots of Polish psychology (s. 34-44). Poznań: Instytut Psychologii UAM.

Rzepa, T. (1993a). O postawie nieinterwencji. Ruch Filozoficzny, L(3), 316-323. Rzepa, T. (1997). Psychologiczny portret Kazimierza Twardowskiego. W: R. Jadczak, Mistrz i jego uczniowie. Warszawa: Wydawnictwo Scholar.

Rzepa, T. (1998). Życie psychiczne i drogi do niego. Psychologiczna Szkoła Lwowska. Szczecin: Wydawnictwo Naukowe Uniwersytetu Szczecińskiego.

Rzepa, T. (2000). Kazimierz Twardowski jako organizator uniwersyteckich środowisk psychologicznych. Przegląd Psychologiczny, 43(1), 15-27. 
Rzepa, T. (2002). O interpretowaniu psychologicznym. W kregu Szkoły Lwowsko-Warszawskiej. Warszawa: Polskie Towarzystwo Semiotyczne.

Rzepa, T. (2014). Kazimierz Twardowski jako mistrz i przełożony. Ruch Filozoficzny, LXXI, 1, 119-134.

Rzepa, T., Dobroczyński, B. (2009). Historia polskiej myśli psychologicznej. Gałazki z drzewa Psyche. Warszawa: Wydawnictwo Naukowe PWN.

Rzepa, T., Stachowski, R. (2011). O tym, kto jest mistrzem dla polskich psychologów i jaki ów mistrz jest. W: T. Rzepa, C.W. Domański (red.), Na drogach $i$ bezdrożach historii psychologii. Lublin: Wydawnictwo UMCS.

Schultz, D.P., Schultz, S.E. (2008). Historia współczesnej psychologii. Kraków: Wydawnictwo UJ.

Tomaszewski, T. (1996). Pejzaż psychologiczny. Warszawa: Wydawnictwo WIP. Twardowski, K. (1897/1965). Psychologia wobec fizjologii i filozofii. W: K. Twardowski, Wybrane pisma filozoficzne. Warszawa: PWN.

Twardowski, K. (1898/1965). Wyobrażenia i pojęcia. W: K. Twardowski, Wybrane pisma filozoficzne. Warszawa: PWN.

Twardowski, K. (1912/1965). O czynnościach i wytworach. W: K. Twardowski, Wybrane pisma filozoficzne. Warszawa: PWN.

Twardowski, K. (1919-1920/1965). O jasnym i niejasnym stylu filozoficznym. W: K. Twardowski, Wybrane pisma filozoficzne. Warszawa: PWN.

Twardowski, K. (1932/1992). O dostojeństwie uniwersytetu. W: K. Twardowski, Wybór pism psychologicznych i pedagogicznych. Warszawa: WSiP.

Twardowski, K. (1992). Autobiografia filozoficzna. Przeglad Filozoficzny. Nowa Seria, $1,19-33$.

Twardowski, K. (1997). Dzienniki, t. 1-2. Toruń: Wydawnictwo Adam Marszałek. Witwicki, W. (1900). Analiza psychologiczna ambicji. Przegląd Filozoficzny, 3, 26-49.

Witwicki, W. (1907). Z psychologii stosunków osobistych. Przegląd Filozoficzny, 10(4), 531-537.

Witwicki, W. (1921). Kazimierz Twardowski. Przeglad Filozoficzny, 22, IX-XIX. Witwicki, W. (1925/1962). Psychologia, t. 1. Lwów: Wydawnictwo Zakładu Narodowego im. Ossolińskich.

Witwicki, W. (1927/1963). Psychologia, t. 2. Lwów: Wydawnictwo Zakładu Narodowego im. Ossolińskich.

Witwicki, W. (1938). Kazimierz Twardowski. Wiadomości Literackie, XV, 18, 1. Woleński, J. (1985). Filozoficzna szkoła lwowsko-warszawska. Warszawa: PWN. Zusne, L. (1975). Names in the history of psychology. A biographical sourcebook. New York, London, Sydney, Toronto: John Wiley \& Sons. 